\title{
A Rare Cause of Acute Respiratory Distress Syndrome: Near Drowning in Detergent and Sodium Hypochlorite Containing Solution
}

\author{
Akut Respiratuvar Distres Sendromunun Seyrek Görülen Bir \\ Nedeni: Deterjan ve Sodyum Hipoklorit İçeren Solüsyonda \\ Boğulayazma
}

Suat Biçer ', Demet Demirkol ${ }^{2}$, Metin Karaböcüoğlu ${ }^{2}$, Agop Çıtak ${ }^{3}$, Nedret Uzel ${ }^{3}$

'Yeditepe Üniversitesi Tıp Fakültesi, Çocuk Sağlığı ve Hastalıkları Ana Bilim Dalı, İstanbul, Türkiye ${ }^{2}$ Bezm-i Alem Üniversitesi, Tıp Fakültesi, Pediatrik Yoğun Bakım, İstanbul, Türkiye

${ }^{3}$ Isstanbul Üniversitesi İstanbul Tıp Fakültesi, Çocuk Acil ve Yoğun Bakım Bilim Dalı, İstanbul, Türkiye

\section{ÖZET}

Boğulayazma çocuklar ve erişkinlerde yüksek morbidite ve mortalite nedeni olmaya devam etmektedir. Çocuk yoğun bakım ünitelerinin ve teknolojinin gelişmesiyle boğulayazma olgularının yaşatılabilirliği de artmıştır. Boğulayazmanın kısa vadeli sağ kalımındaki gelişmeye karşın, kurbanlarda akut solunum yetmezliği sendromu ve kalıcı hipoksik-iskemik merkezi sinir sistemi hasarında artışa neden olmuştur. Bu nedenle, batma olayı sonrası kurbanların akut dönemde yoğun bakımdaki tedavisi önemlidir. Bu yazıda, sodyum hipoklorit ve deterjan içeren su dolu kova içinde gerçekleşen boğulayazma olgusu sunulmuşturCAYD 2015;2(1):49-54.

Anah tar Ke limeler: Akut solunum yetmezliği sendromu, boğulayazma, hipoksik-iskemik merkezi sinir sistemi hasarı, sodyum hipoklorit

\section{SUMMARY}

Near-drowning continues to be associated with high mortality and morbidity in both children and adults. With the availability of sophisticated technologies and pediatric intensive care units, victims of near-drowning are now more likely to survive. However this improvement in short-term survival of near-drowning, victims after an acute submersion episode has also resulted in an increase of acute respiratory distress syndrome and persistent hypoxic-ischemic central nervous system injury. Therefore, it is important both to know the acute intensive care unit management of victims of neardrowning and also to understand the progression of the disease. We report a patient who had been near-drowned in bucket filled with sodium hypochlorite and detergent containing waterCAYD 2015;2(1):49-54.

Keyw ords: Acute respiratory distress syndrome, hypoxic-ischemic central nervous system injury, near-drowning, sodium hypochlorite 


\section{INTRODUCTION}

Drowning, defined as a process resulting in primary respiratory impairment from submersion/immersion in a liquid medium, is a major cause of pediatric unintentional death worldwide (1-3). Drowning continues to be associated with high mortality and morbidity in both children and adults. Although differences in lifestyle and exposure to water may affect the circumstances under which drowning occurs in different countries, drowning consistently remains a leading cause of death throughout the world (2). Near-drowning, defined as survival following submersion, was described as a clinical problem in pediatric intensive care units (1). With the availability of sophisticated technologies and pediatric intensive care units, victims of near-drowning are now more likely to survive (4-7). However this improvement in short-term survival of near-drowning, victims after an acute submersion episode has also resulted in an increase of acute respiratory distress syndrome (ARDS) and persistent hypoxic-ischemic central nervous system (CNS) injury (8). Therefore, it is important for the acute intensive care unit (ICU) management of victims of near-drowning but also understand the progression of the disease.

Household bleaches that contain sodium hypochlorite $(\mathrm{NaOCl})$ and sodium hydroxide are the common domestic agents used all around the world, which are frequently accidently ingested by children (9). Commercial household bleaches are known to have minor adverse effects when ingested, as being mucosal irritants, emetics and weak corrosives. However, our clinical observations of pneumonitis among household bleach ingested by patients without a history of aspiration foretell some possible systemic toxic effects of household bleaches (9).

We report a patient who had been near-drowned in bucket filled with $\mathrm{NaOCl}$ and detergent containing water.

\section{CASE REPORT}

A 11-months old boy who had been pulled from bucket filled with sodium $\mathrm{NaOCl}$ and detergent containing water. Her mother left the child was behind the bucket. The bucket was approximately one-half full of water. The mother was gone approximately five minutes, and upon returning she found the child's head in the bucket. Five minutes later, they arrived at the hospital. After the initial resuscitation he was transported to our pediatric intensive care unit. On physical examination the patient was lethargic, Glasgow Coma Scale (GCS) score was 10 point. He has cyanosis, with a heart rate $160 /$ minute, respiratory rate $60 /$ minute, temperature $36^{\circ} \mathrm{C}$, arterial blood pressure $75 / 40 \mathrm{~mm} \mathrm{Hg}$, and delayed capillary refill time (5 seconds). Oral mucosa was hyperemic with hypersalivation. He was tachypneic, respiratory efforts were irregular with retractions and rales on auscultation. His cardiac examination findings were unremarkable. Abdomen was soft and no tender. Tonus was decreased. Pupils were bilaterally equal and reactive. The patient was intubated and ventilated immediately, because of severe hypoxemia. Initial fluid resuscitation was done. The seizure was observed and treated with anticonvulsant drugs. The chest $x$-ray showed small patchy diffuse pulmonary infiltrates. ARDS was developed on the first day. $\mathrm{PaO}_{2} / \mathrm{FiO}_{2}$ was found low (80). Low tidal volume with high PEEP was applied as mechanical ventilation strategy. Bilateral pneumothorax was developed in the second hospitalization day. On the 21th hospital day, tracheotomy operation was done because of the weaning difficulty. On the 30th hospital day, the patient weaned from the ventilator. The patchy ground-glass opacities, parenchymal fibrosis and traction bronchiectasis were showed in high-resolution computed tomography (HRCT) examination (Figure 1). Fibrosis was revealed after 11 months by HRCT (Figure 2). Bilateral basal ganglia infarcts were showed in cranial magnetic resonance imaging (Figure 3). Tracheotomy was closed at 2.5 months after the admission. The patient was discharged from the hospital with severe neurological sequela.

\section{DISCUSSION}

Drowning is a major cause of pediatric unintentional death worldwide (3). It is the third leading cause of death in children aged 1-5 and the leading cause of mortality due to injury, with the mortality rates in male children being almost twice as high as those in female children (3). Young children under the age of 5 are at particularly increased risk of drowning, with drowning rates peaking among children ages 1 to 2 years $(5,10-12)$. Death by drowning is not the sole outcome of distress in the water. Near-drowning is also a serious problem. One study (13) found that for every 10 children who die by drowning, 140 are treated in emergency rooms and 36 are admitted to hospitals for further treatment $(14,15)$, although some never recover $(14,17)$. 


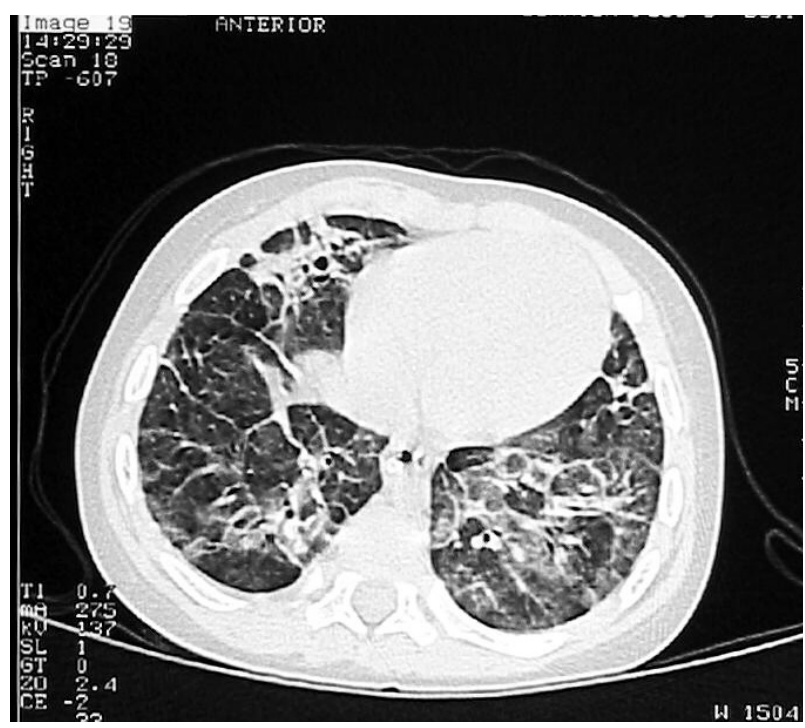

Şekil 1. High-resolution computed tomography (HRCT) examination showed patchy ground-glass opacities, parenchymal fibrosis and traction bronchiectasis.

This is a very lethal injury; $50 \%$ of pediatric submersion victims die which is among the highest percentage of all ruptured injuries (1). In Uganda, drowning has been shown to be responsible for $27 \%$ of all injury fatality (16). Death by drowning is not the sole outcome of distress in the water. In the Netherlands, it has been reported that on average there are about 300 drowning fatalities a year and an additional 450 cases who survive the drowning incident, of these 390 are admitted to hospital for further treatment (18). The recovery rate from neardrowning may be lower among young children than among teenagers and adults. Some survivors suffer subsequent hypoxic encephalopathy, leading to long-term neurological deficits $(7,11,19,20)$.

Drowning rates vary with age in discernible percentage (1). Drowning rates are highest among children younger than 5 years and second highest among 15 to 19-year-olds (1). As with all injuries males predominate $(3,21)$. Males, however, predominate even in the earliest age-groups, possibly because young boys are often granted more freedom from supervision than young girls enjoy, making it more likely that they will stumble into danger and less likely that they will attract an adult's attention in time for a quick rescue. Submersion among infants younger than 1 year of age usually occur in bathtubs, 1 to 4 year olds typically fall into swimming pools $(4,11,23)$. More than $50 \%$ of unintentional infant drowning deaths occur in the bathtub (24).

Among children ages 14 and younger, toddlers are at particularly high risk, both in large bodies of

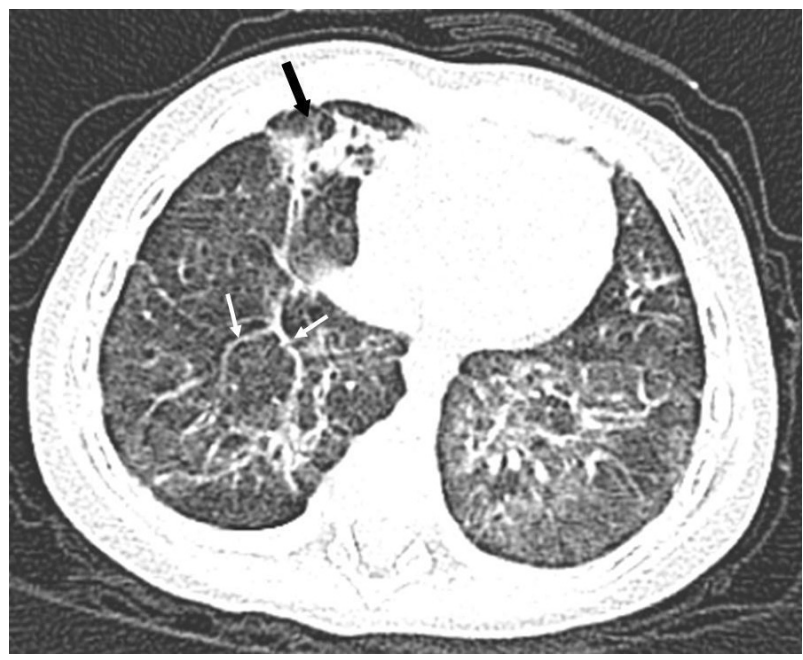

Şekil 2. HRCT obtained 11 months later revealed mostly fibrosis.

water, such as pools, rivers, lakes or irrigation ditches, as well as smaller bodies of water, such as bathtubs, fountains or even buckets. Small children have drowned or almost drowned in bathtubs, toilets, industrial-size cleaning buckets, and washing machines (8) Drownings in this age group frequently occur during a lapse in supervision (25). The majority of bathtub drownings involved children under age five. Buckets may be common risk sites (26). Our patient was 11-months old, male and was neardrowned in bucket. Hypoxemia has been described as the single most important consequence of neardrowning (27). Individuals who survive the initial course near-drowning are at risk for the development secondary drowning: the development of ARDS (25). In our patient additive risk factor for development of ARDS was, near-drowned in water containing sodium hypochlorite. Bleaches based on solutions of $\mathrm{NaOCl}$ are widely used in the household to disinfect and clean hard surfaces and to bleach the laundry. (9). Commercial household bleaches are known to have minor adverse effects, but they cause pneumonitis even though they ingested via gastric way (9). When they aspirate from the respiratory tract, acute respiratory failure may occur $(28,29)$. In household bleaches aspiration, late death occur especially from progressive lung damage $(28,30)$. Our pateint serial HRCT examination of the lungs showed especially fibrosis, no progression or regression was found on control HRCT imaging.

The majority of patients entering the ICU in a flaccid, comatose state will suffer cerebral death or 


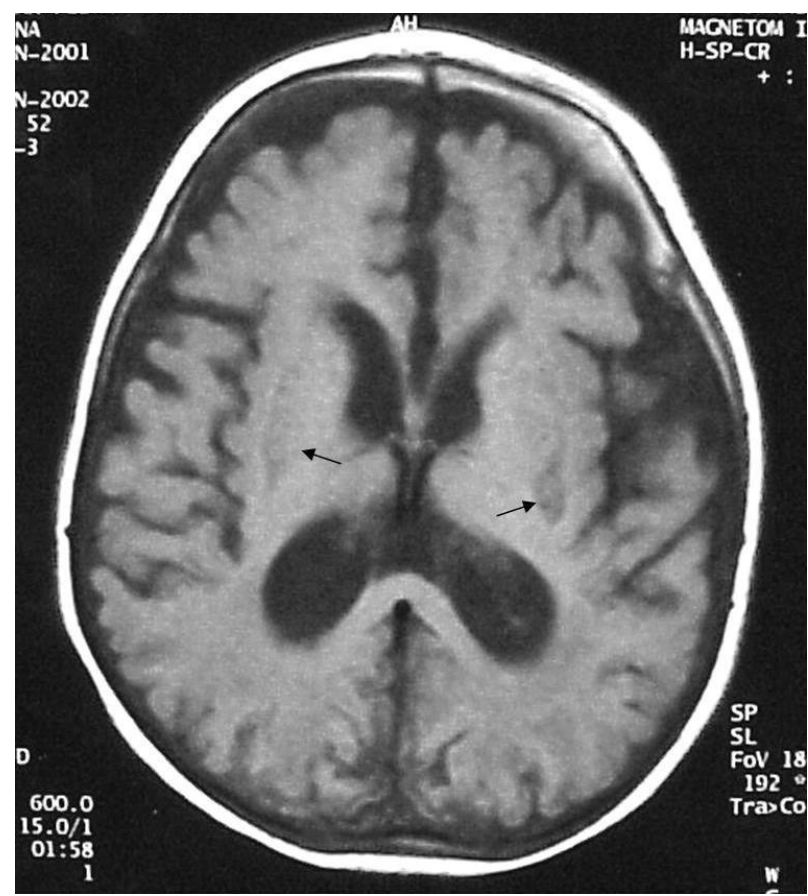

Şekil 3. Bilateral basal ganglia infarcts were showed in cranial magnetic resonance imaging.

severe long-term neurologic sequelae. Trials aimed at restoring hypoxic-damaged brain have been largely unsuccessful (31). However, as many as 30\% of patients will survive as neurologically intact (32), predicting the outcome in individual patients has proven to be difficult. Suggested indicators include: temperature of submersion medium (33), duration of submersion, GCS, rapidity of restoration of heart rate, state of pupils, minimum blood $\mathrm{pH}$, intracranial pressure, reduction in regional blood flow, EEG, and blood glucose (34). CNS dysfunction may be secondary to the initial hypoxic injury and may be caused by progressive CNS injury because of post resuscitation cerebral hypoperfusion. Studies have results suggest that pupillary unresponsiveness in the emergency department and initial GCS score of less than 5 on arrival to the ICU are associated independently with poor CNS outcome (35). Intact survival is associated with submersion durations fewer than 5 minutes (36). Even though at admission GCS was 11 and pupils were reactive in our patient, he developed severe hypoxic-ischemic injury. Duration of submersion may be more predictive for CNS injury. A prognosis score for pediatric near-drowning victims has been derived by Orlowski (33). It is based on five indicators: age younger than 3 year, maximum submersion estimated longer than $5 \mathrm{~min}$, post-rescue delay in resuscitation for greater than $10 \mathrm{~min}$, coma at time of admission and initial $\mathrm{pH}$ less than or equal to 7.1 (33). We thought that our patient's submersion duration was longer than 5 minutes.

Remarkably, submersion injury has received little attention even though the number of drowning in most countries greater than the total number of drowning in most countries. The key to minimizing morbidity and mortality secondary to submersion accidents is successful prevention.

The mortality rates of ARDS were reported from $18.2 \%$ to $70 \%$ (37-40). This wide disparity in mortality could be related to many factors including causes and severity of illness. The most common causes of ARDS were sepsis, extra-pulmonary organ failure, multiple trauma, and lung diseases including pneumonia, lung contusion, drowning (37-40). The rate of drowning as a cause of ARDS was reported $\% 2$ by Li et al (40).

\section{CONCLUSION}

Lack of adult supervision and judgment is by far the biggest risk factor related to the drowning death of a young child. Infants most often drown in bathtubs when left unattended or when the supervising adult becomes distracted. Because even nonfatal drownings can be serious, with many requiring hospitalization and some resulting in brain damage or other long-term adverse effects, prevention is critical. Many patients who have nearly drowned and who need ventilatory support may develop ARDS. Despite agressive care, neurologic injury with long term sequelae secondary to hypoxic ischemic injury remains a major problem in the management of submersion accidents. Prevention is important in the chain of survival for the submersion victim. Participants, parents, caregivers, and supervisors should be aware of the hazards, use appropriate prevention strategies, and be prepared with the skills to save lives in the event of emergencies.

\section{KAYNAKLAR}

1. Quan L. Near-Drowning. Pediatrics in Review 1999; 20:255-60.

2. Meyer RJ, Theodorou AA, Berg RA. Childhood Drowning. Pediatrics in Review. 2006;27:163-9.

3. Peden MM, McGee K. The epidemiology of drowning worldwide. Inj Control Saf Promot 2003;10:195-9.

4. Jensen LR, Williams SD, Thurman DJ, Keller PA. Submersion injuries in children younger than 5 years in urban Utah. West J Med 1992;157:641-4.

5. Wintemute GJ: Childhood drowning and near-drowning in the United States. Am J Dis Child 1990;144:663-9.

6. Brooks JG. Near drowning. Pediatr Rev 1988;10:5-10. 
7. Pearn J. Neurological and psychometric studies in children surviving freshwater immersion accidents. Lancet 1977;1:7-9.

8. Centers for Disease Control and Prevention National Center for Injury Prevention and Control. Water- Related Injuries: Fact Sheet. Available at:

http://www.cdc.gov/ncipic/factsheets/drown.htm Accessed December 3,2006.

9. Andiran F, Tanyel FC, Ayhan A, Hicsonmez A. Systemic harmful effects of ingestion of household bleaches. Drug Chem Toxicol 1999;22:545-53.

10. Gulaid JA, Sattin RW. Drownings in the United States, 1978-1984. MMWR 1988;37:27-33.

11. Quan L, Gore EJ, Wentz K, Allen J, Novack AH. Ten-year study of pediatric drownings and near-drownings in King County, Washington: lessons in injury prevention. Pediatrics 1989;83:1035-40

12. Brenner RA, Smith GS, Overpeck MD. Divergent trends in childhood drowning rates, 1971 through 1988. JAMA 1994;271:1606-8.

13. Wintemute GJ, Kraus JF, Teret SP, Wright MA. The epidemiology of drowning in adulthood: implications for prevention. Am J Prev Med. 1988;4:343-8.

14. Spyker DA. Submersion injury. Epidemiology, prevention and management. Pediatric Clinics of North America 1985:32:113-25

15. Liller KD, Kent EB, Arcari C, McDermott RJ. Risk factors for drowning and near-drowning among children in Hillsborough County, Florida. Public Health Rep. 1993; 108:346-3.

16. Kobusingye $\mathrm{O}$. The global burden of drowning: An African Perspective. In: Bierens J, ed. Handbook on drowning. Prevention, rescue and treatment. Heidelberg: Springer-Verlag, 2006: 61-62.

17. Wintemute GJ, Kraus JF, Teret SP, Wright MA. The epidemiology of drowning in adulthood: Implications for prevention. American Journal of Preventive Medicine 1988:4:343-8.

18. Bierens JJLM. 2944 submersion victims: an analysis of external causes, concomitant risk factors, complications and prognosis. Netherlands, University of Utrecht In: Drownings in the Netherlands. Pathophysiology, epidemiology and clinical studies. PhD thesis.

19. Branche $C$, van Beeck $E$, eds. The epidemiology of drowning, Sec. 2, p. 39-76 IN: Bierens Joost JLM, ed., 2005, Handbook on Drowning: Prevention, Rescue, Treatment, Springer Verlag, Heidelberg Germany, 713 p. Retrieved 4/7/2012 http://www.ncbi.nlm.nih.gov/nlmcatalog/101261179

20. Pearn J, Nixon J, Wilkey I. Freshwater drowning and neardrowning accidents involving children: a five-year total population study. Medical Journal of Australia 1976;2: 942-6.

21. MMWR Morbidity and Mortality Weekly Report. Nonfatal and Fatal Drownings in Recreational Water SettingsUnited States, 2001-2002 MMWR. JAMA 2004;292: (Reprinted) 164-6.

22. O'Carroll PW, Alkon E, Weiss B: Drowning mortality in Los Angeles County, 1976 to 1984. JAMA 1988;260:380-3.

23. Davis S, Ledman J, Kilgore J. Drownings of children and youth in a desert state. West J Med 1985;143:196-201.
24. National Center for Health Statistics. Public use data tapes. Compressed Mortality Files: 1983-1994. Hyattsville, MD: US Department of Health and Human Services)

25. van Beeck EF, Branche CM, Szpilman D, Modell JH, Bierens JJ. A new definition of drowning: towards documentation and prevention of a global public health problem. Bull World Health Organ 2005;83:853-6.

26. Colorado Department of Public Health and Environment, Injury, Suicide and Violence Prevention Section. (2004). Drowning Deaths and Near-Drowning Incidents among Colorado Children Ages 0-14,1998-2002. Retrieved March 10, 2005, from

http://www.cdphe.state.co.us/pp/injuryprevention/SK DrowningFactSheet.pdf., Drowning and submersion (Chapter eight. In: Injury in Colorado: Colorado Department of Public Health and Environment. p 107-14.

27. Golden FC, Tipton MJ, Scott RC. Immersion, near-drowning and drowning. Br J Anaesth 1997;79:214-25.

28. Karnak I, Tanyel C, Büyükpamukçu N, Hiçsönmez A. Pulmonary Effects of Household Bleach Ingestion in Children. Clin Pediatr (Phila) 1996;35;471.

29. Tanyel FC, Büyükpamukçu N, Hiçsönmez A. Chlorine bleach ingestion in children: a review of 80 cases. Turkish J Pediatr 1988;30:105-8.

30. Reisz GR, Gammon RS. Toxic pneumonitis from mixing household cleaners. Chest 1986;8:49-52.

31. Modell JH. Drowning. N Engl J Med 1993;328: 253-6.

32. Witte MK. Near-drowning. In: Practical Guide to Pediatric Intensive Care. JL Blumer, editor. Mosby, St. Louis, 1990;313-7.

33. Orlowski JP. Drowning, near-drowning, ice-water submersions. Pediatr Clin North Am 1987;34:75-92.

34. Ashwal S, Schneider S, Tomasi L, Thompson J. Prognostic implications of hyperglycemia and reduced cerebral blood flow in childhood near-drowning. Neurology 1990; 40:820-3.

35. Dean JM, Kaufman ND. Prognostic indicators in paediatric near-drowning: The Glasgow Coma Scale. Critical Care Medicine 1981;9:536-9.

36. Golden F St C, Tipton MJ, Scott RC. Immersion, neardrowning and drowning. British Journal of Anaesthesia 1997;79:214-25.

37. Rubenfeld GD, Caldwell E, Peabody E, Weaver J, Martin DP, Neff $M$, et al. Incidence and outcomes of acute lung injury. N Engl J Med 2005;353:1685-93.

38. Flori HR, Glidden DV, Rutherford GW, Matthay MA. Pediatric acute lung injury: prospective evaluation of risk factors associated with mortality. Am J Respir Crit Care Med 2005;171:995-1001.

39. Erickson S, Schibler A, Numa A, Nuthall G, Yung $M$, Pascoe $E$, et al. Acute lung injury in pediatric intensive care in Australia and New Zealand: a prospective, multicenter, observational study. Pediatr Crit Care Med 2007;8:317-23

40. Li Y, Wang Q, Chen H, Gao HM, Zhou T, Qian SY. Epidemiological features and risk factor analysis of children with acute lung injury. World J Pediatr 2012;8:43-6. 
